\title{
Adriana Politaj
}

Uniwersytet Ekonomiczny we Wrocławu

e-mail: adriana.politaj@ue.wroc.pl

\section{PAŃSTWOWE FUNDUSZE CELOWE JAKO ŹRÓDLO WSPARCIA FINANSOWEGO SPÓŁDZIELNI SOCJALNYCH W POLSCE}

\section{STATE SPECIAL PURPOSE FUNDS AS A SOURCE OF FINANCIAL SUPPORT FOR SOCIAL COOPERATIVES IN POLAND}

DOI: $10.15611 /$ nof.2017.1.05

JEL Classification: J23

\begin{abstract}
Streszczenie: Spółdzielnie socjalne stanowią specyficzny rodzaj podmiotów gospodarczych, których cele gospodarcze łączą się z realizacją funkcji społecznych. Dynamiczny rozwój tego sektora przedsiębiorstw społecznych wskazuje na duże zainteresowanie taką formą zatrudnienia i reintegracji. Specyficzna formuła działania tych podmiotów, oparta na pracy spółdzielczej osób marginalizowanych i często pozbawionych umiejętności biznesowych, wymaga stosowania ze strony państwa szerokiej pomocy, i to nie tylko finansowej, szczególnie w początkowych okresach ich funkcjonowania. Przyznawana bowiem pomoc finansowa ze środków publicznych - głównie z Funduszu Pracy i Państwowego Funduszu Rehabilitacji Osób Niepełnosprawnych - okazuje się niewystarczającą formą pomocy dla wielu tego typu podmiotów. Blisko połowa z nich nie rozpoczyna faktycznie działalności lub nie osiąga żadnych dochodów. Celem niniejszego artykułu jest próba identyfikacji finansowego wsparcia spółdzielni socjalnych w Polsce udzielanego corocznie ze środków wybranych państwowych funduszy celowych oraz określenie roli tego sektora przedsiębiorstw gospodarki społecznej w procesie wsparcia zatrudnienia i przeciwdziałania marginalizacji społecznej osób bezrobotnych.
\end{abstract}

Słowa kluczowe: rynek pracy, osoby niepełnosprawne, fundusze celowe.

Summary: Social cooperatives are a specific type of entrepreneurs, whose economic goals are combined with the implementation of social functions. The dynamic development of this sector of social enterprises indicates a strong interest in this form of employment and reintegration. The specific formulation of these entities, based on the work of cooperative marginalized and often lacking business skills requires wide support from the state, especially in the initial period of their existence and not just financial. Financial support from public funds - mainly from the Labour Fund and the State Fund for Rehabilitation of Disabled Persons turns out to be an insufficient form of help for many of these entities. Nearly half of them do not actually starts activity or receive any income. The purpose of this paper is to identify the financial support of social cooperatives in Poland granted annually by the state funds and to determine the role of this sector of social economy enterprises in the process of employment support and counter social marginalization of the unemployed.

Keywords: labour market, handicapped persons, state special purpose funds. 


\section{Wstęp}

Osoby bezrobotne, w szczególności długotrwale, zaliczane są do grup defaworyzowanych na rynku pracy i trudnych z punktu widzenia realizowanych na ich rzecz aktywnych instrumentów rynku pracy. Tego typu osoby są szczególnie podatne na marginalizację. Często popadają w konflikt z prawem i nałogi. Postępujący proces ich marginalizacji często jest trudno odwracalny [Politaj 2010]. Oprócz osób bezrobotnych do subpopulacji defaworyzowanych na rynku pracy zalicza się też osoby niepełnosprawne, osoby opuszczające zakłady karne oraz ośrodki leczenia uzależnień, a także osoby bez jakichkolwiek kwalifikacji zawodowych, matki samotnie wychowujące dzieci czy też osoby powyżej 50. roku życia [Rusin i in. 2010]. Działania publicznych służb zatrudnienia na rzecz ich przywrócenia na rynek pracy są mało skuteczne, a pochłaniają corocznie znaczne kwoty.

Zatrudnienie osób marginalizowanych z powodu bezrobocia w spółdzielniach socjalnych wydaje się jednym z najlepszych sposobów w zakresie ich wkluczenia. Spółdzielnie socjalne są przedsiębiorstwami ukierunkowanymi na produkcję dóbr oraz usług i charakteryzują się wysokim zaufaniem społecznym. Odgrywają kluczową rolę $\mathrm{w}$ pośrednictwie między prywatnym sektorem i instytucjami publicznymi oraz wspólnotami społecznymi. Podobnie jak inne organizacje non-profit, spółdzielnie socjalne stanowią kompromis między poszanowaniem wartości moralnych i maksymalizacją prywatnych korzyści ich członków [Bartoli, Palombo 2009].

Początki spółdzielczości socjalnej w Polsce datuje się na lata dziewięćdziesiąte ubiegłego wieku. Jednakże spółdzielnie socjalne zostały prawnie usankcjonowane dopiero w 2003 r. i właściwie od tego momentu obserwuje się szczególny rozwój tego sektora przedsiębiorstw gospodarki społecznej w Polsce. Spółdzielniom socjalnym w naszym kraju przyznano szczególne formy wsparcia finansowego. Dzięki tym instrumentom finansowym miały się one stać skutecznym narzędziem w procesie reintegracji społecznej i zawodowej grup defaworyzowanych na rynku pracy.

Celem niniejszego opracowania jest próba identyfikacji finansowego wsparcia spółdzielni socjalnych w Polsce udzielanego corocznie ze środków wybranych państwowych funduszy celowych oraz określenie roli tego sektora przedsiębiorstw gospodarki społecznej w procesie wsparcia zatrudnienia i przeciwdziałania marginalizacji społecznej osób bezrobotnych. Na potrzeby opracowania sformułowano następującą hipotezę badawczą: środki finansowe przyznawane spółdzielniom socjalnym z państwowych funduszy celowych stanowią istotne źródło wsparcia finansowego tego sektora przedsiębiorstw gospodarki społecznej i cechują się znaczną efektywnością w zakresie aktywizacji zawodowej osób marginalizowanych z powodu bezrobocia.

Zakres czasowy opracowania ustalono na lata 2010-2015. Zastosowano następujące metody badawcze: metodę krytyki piśmiennictwa i aktów prawnych oraz metody statystyczne z zakresu analizy danych statystycznych. 


\section{Geneza spóldzielczości socjalnej w Polsce}

Geneza spółdzielczości socjalnej sięga końca lat siedemdziesiątych ubiegłego stulecia we Włoszech i jest związana m.in. z poszukiwaniem nowych rozwiązań w zakresie przeciwdziałania marginalizacji społecznej grup defaworyzowanych na rynku pracy. Przez wiele lat bowiem funkcjonujące systemy przeciwdziałania bezrobociu okazywały się nieefektywne w zakresie wsparcia powrotu na rynek pracy tzw. trudnych subpopulacji osób wykluczonych z przyczyn bezrobocia [Thomas 2004]. Pierwotnie spółdzielnie socjalne we Włoszech działały na prawach regulujących ogólny ruch spółdzielczy (podobna sytuacja wystąpiła w wielu innych krajach w początkowej fazie tworzenia się spółdzielczości socjalnej) i dopiero w $1991 \mathrm{r}$. ich funkcjonowanie uregulowano odrębnym aktem prawnym, tj. ustawą z dnia 8 lipca $1991 \mathrm{r}$. nr 381 o spółdzielniach socjalnych [Legge 8 novembre 1991]. W artykule 1. tegoż aktu prawnego zapisano, że celem działania spółdzielni socjalnych jest dążenie do zaspokajania ogólnego interesu społeczeństwa oraz do promocji i integracji społecznej przez: a) zarządzanie usługami socjalnymi, zdrowotnymi i edukacyjnymi, b) świadczenie różnych usług w takich sferach, jak rolnictwo, przemysł, przedsiębiorczość oraz zawodowa integracja grup defaworyzowanych. Ze względu na wymienione cele funkcjonowania spółdzielni socjalnych w praktyce wykształciły się dwa typy (rodzaje) spółdzielni socjalnych. Typ A spółdzielni socjalnych zapewnia usługi w zakresie opieki zdrowotnej, socjalnej lub edukacyjnej. Spółdzielnie typu B działają na rzecz włączenia w rynek pracy osób ze środowisk dyskryminowanych [Borzaga, Santuari 2000]. Do grup docelowych tych spółdzielni należą m.in.: osoby fizycznie lub umysłowo niepełnosprawne, uzależnione od alkoholu lub narkotyków. Organizacje te zajmują się również osobami mającymi problemy z prawem [Johnson, Spear 2006]. Rozwiązania dotyczące włoskiej spółdzielczości socjalnej znalazły zastosowanie w wielu krajach europejskich i na innych kontynentach.

Polskie rozwiązania $\mathrm{w}$ zakresie spółdzielni socjalnych wzorowane są na włoskich spółdzielniach typu B. Pierwotnie działały one w oparciu o ogólne ramy prawne regulujące ruch spółdzielczy, tj. w oparciu o ustawę z dnia 16 września $1982 \mathrm{r}$. Prawo spółdzielcze. Jednak po roku 1989 spółdzielnie w Polsce pozbawiono wielu uprawnień, dlatego też potrzebne były nowe rozwiązania odwołujące się do krajowych doświadczeń. Pierwsze ogólne regulacje prawne dotyczące spółdzielni socjalnych w prawie spółdzielczym pojawiły się jednak dopiero w 2003 roku. Natomiast szczegółowe uregulowania tworzenia i działalności spółdzielni socjalnych w Polsce wprowadzono na mocy ustawy z dnia 13 czerwca 2003 r. o zatrudnieniu socjalnym, a także innych ustaw, m.in. ustawy z dnia 20 kwietnia 2004 r. o promocji zatrudnienia i instytucjach rynku pracy. Aktualną podstawą prawną do działania spółdzielni socjalnych jest ustawa z dnia 27 kwietnia 2006 r. o spółdzielniach socjalnych.

W świetle zawartych w tym akcie zapisów spółdzielnia socjalna działa na rzecz:

1) społecznej reintegracji jej członków, przez co należy rozumieć działania mające na celu odbudowanie i podtrzymanie umiejętności uczestniczenia w życiu spo- 
łeczności lokalnej i odgrywania ról społecznych w miejscu pracy, zamieszkania lub pobytu,

2) zawodowej reintegracji jej członków, przez co należy rozumieć działania mające na celu odbudowanie i podtrzymanie zdolności do samodzielnego świadczenia pracy na rynku pracy - a działania te nie są wykonywane w ramach prowadzonej przez spółdzielnię socjalną działalności gospodarczej.

Spółdzielnię socjalną mogą założyć osoby z pełną zdolnością do czynności prawnych i równocześnie zaliczające się do przynajmniej jednej z następujących kategorii: bezrobotni, niepełnosprawni, uzależnieni od alkoholu, narkotyków lub środków odurzających po zakończeniu leczenia, chorzy psychicznie, bezdomni realizujący indywidualny program wychodzenia z bezdomności, osoby opuszczające więzienie, które mają trudności z reintegracją społeczną, uchodźcy uczestniczący $\mathrm{w}$ indywidualnym programie integracji oraz inne osoby, pod warunkiem że ich liczba nie przekracza 50\% ogólnej liczby założycieli [Ustawa z dnia 14 lipca 2014 r.]. Założycielami spółdzielni socjalnej mogą być ponadto: organizacje pozarządowe (w rozumieniu przepisów o działalności pożytku publicznego i o wolontariacie) lub jednostki samorządu terytorialnego, kościelne osoby prawne.

Liczba założycieli spółdzielni socjalnej nie może być mniejsza niż pięć, jeżeli założycielami są osoby fizyczne, i dwa, jeżeli założycielami są osoby prawne. Spółdzielnia socjalna nie może liczyć więcej niż 50 członków ${ }^{1}$.

Przyjęcie takiego rozwiązania podyktowane było, z jednej strony, chęcią stworzenia możliwości prowadzenia wspólnej działalności dla osób, które samodzielnie miałyby trudności w podjęciu działalności gospodarczej, z drugiej zaś - koniecznością stworzenia optymalnych warunków do reintegracji społecznej członków spółdzielni, w tym tworzenia i wzmacniania więzi międzyludzkich.

Poza wyżej wymienionymi osobami członkostwo w założonej spółdzielni mogą nabyć osoby zagrożone wykluczeniem społecznym z ograniczoną zdolnością do czynności prawnych. Możliwy jest również udział osób nieposiadających statusu wykluczonych, lecz przydatnych dla spółdzielni ze względu na kwalifikacje, których nie posiadają pozostali spółdzielcy. Ich liczba nie może przekroczyć $50 \%$ ogólnej liczby członków spółdzielni oraz osób zatrudnionych nieprzerwanie przez okres 12 miesięcy w spółdzielni socjalnej, której założycielami były osoby prawne. Ponadto członkami mogą być (jeśli statut nie stanowi inaczej) organizacje pozarządowe, których celem nie jest osiąganie zysku, np. fundacje, stowarzyszenia, kościelne osoby prawne, a także jednostki samorządu terytorialnego, jak np. powiat czy gmina. Bez prawa członkostwa pracę na rzecz spółdzielni socjalnej mogą wykonywać osoby skazane na karę ograniczenia wolności oraz wolontariusze.

Spółdzielnia socjalna jest osobą prawną w rozumieniu przepisów ustawy z dnia 23 kwietnia 1964 r. Kodeks cywilny z momentem jej wpisu do Krajowego Rejestru

${ }^{1}$ Spółdzielnia socjalna, która powstała w wyniku przekształcenia spółdzielni inwalidów lub spółdzielni niewidomych, może liczyć więcej niż 50 członków. 
Sądowego jako przedsiębiorcy. Spółdzielnia socjalna zatem, tak jak inne spółdzielnie działające w Polsce, funkcjonuje jako przedsiębiorstwo i podlega podobnej procedurze rejestracyjnej oraz przepisom, które dotyczą przedsiębiorców.

\section{Podstawy gospodarki finansowej spółdzielni socjalnych w Polsce}

Spółdzielnie socjalne opierają swoje podstawy finansowe na dwóch filarach, tj. na środkach własnych - uzyskanych w trakcie prowadzonej działalności o charakterze gospodarczym (finansowanie wewnętrzne) oraz na pomocy szeroko rozumianego państwa - głównie z państwowych funduszy celowych, Europejskiego Funduszu Społecznego oraz samorządów (finansowanie zewnętrzne).

Pomoc finansowa ze strony państwa ma charakter obligatoryjny i fakultatywny (tab. 1). Ważne jest, że pomoc finansowa przysługuje spółdzielni socjalnej jako instytucji oraz jej poszczególnym członkom. Ponadto istotny jest też etap działania spółdzielni, gdyż niektóre formy pomocy są dostępne wyłącznie w fazie tworzenia spółdzielni, a inne w trakcie jej działania.

Jako pomoc pewna (obligatoryjna) trafia do spółdzielni w momencie jej zakładania w postaci zwolnienia z opłat za wpis spółdzielni do Krajowego Rejestru Sądowego (KRS) oraz ogłoszenia tego zdarzenia w Monitorze Sądowym i Gospodarczym. Również bezpłatne są dla spółdzielni socjalnej zmiany wpisu w KRS.

Tabela 1. Obligatoryjne i fakultatywne źródła finansowania spółdzielni socjalnych w Polsce (stan na 10.12.2016)

\begin{tabular}{|c|c|c|c|}
\hline & Wyszczególnienie & Beneficjent & Uwagi \\
\hline & 1 & 2 & 3 \\
\hline \multicolumn{4}{|c|}{ Pomoc pewna (obligatoryjna) } \\
\hline 1 & $\begin{array}{l}\text { Zwolnienie z opłat rejestracyjnych } \\
\text { za wpis do KRS oraz zwolnienie od } \\
\text { uiszczania opłat od wniosków za } \\
\text { kolejne wpisy w rejestrze. } \\
\text { Wydrukowanie ogłoszenia wpisu } \\
\text { do KRS w Monitorze Sądowym } \\
\text { i Gospodarczym }\end{array}$ & spółdzielnia socjalna & $\begin{array}{l}\text { opłaty te wynoszą: } \\
\text { - wpis do rejestru } 500 \mathrm{zl} \text {, } \\
\text { - zmiana wpisu } 150 \mathrm{zl} \text {, } \\
\text { - wykreślenie z rejestru } 250 \mathrm{zl} \text {, } \\
\text { - wydrukowanie ogłoszenia } \\
100 \mathrm{zł}\end{array}$ \\
\hline \multicolumn{4}{|c|}{ Pomoc fakultatywna (warunkowa) } \\
\hline 1 & $\begin{array}{l}\text { Zwolnienie z podatku } \\
\text { dochodowego od osób prawnych } \\
\text { (CIT) dochodów wydatkowanych } \\
\text { w roku podatkowym na społeczną } \\
\text { i zawodową reintegrację jej } \\
\text { członków w części niezaliczonej do } \\
\text { kosztów uzyskania przychodów }\end{array}$ & spółdzielnia socjalna & $19 \%$ od osiągniętego dochodu \\
\hline
\end{tabular}




\begin{tabular}{|c|c|c|c|}
\hline \multicolumn{2}{|r|}{1} & 2 & 3 \\
\hline 2 & $\begin{array}{l}\text { Jednorazowe środki z Funduszu } \\
\text { Pracy na podjęcie działalności } \\
\text { gospodarczej: do kwoty 4-krotnej } \\
\text { wysokości przeciętnego } \\
\text { wynagrodzenia na każdego członka } \\
\text { założyciela spółdzielni }\end{array}$ & $\begin{array}{l}\text { bezrobotny } \\
\text { zarejestrowany w pup; } \\
\text { absolwent Centrum } \\
\text { Integracji Społecznej } \\
\text { lub absolwent Klubu } \\
\text { Integracji Społecznej }\end{array}$ & do kwoty $16220,16 \mathrm{zl}$ \\
\hline 3 & \begin{tabular}{|l} 
Jednorazowe środki z Funduszu \\
Pracy na wniesienie wkładu do \\
spółdzielni socjalnej do kwoty \\
3-krotnej wysokości przeciętnego \\
wynagrodzenia na każdego członka \\
przystępującego do już istniejącej \\
spółdzielni socjalnej
\end{tabular} & jak wyżej & do kwoty 12 165,12 zł \\
\hline 4 & $\begin{array}{l}\text { Sfinansowanie ze środków } \\
\text { Funduszu Pracy składek na } \\
\text { ubezpieczenie emerytalne, rentowe } \\
\text { i wypadkowe }\end{array}$ & członek spółdzielni & $\begin{array}{l}\text { w pełnej wysokości przez } \\
\text { okres } 24 \text { miesięcy od dnia } \\
\text { zatrudnienia oraz w połowie } \\
\text { wysokości przez kolejne } \\
12 \text { miesięcy }\end{array}$ \\
\hline 5 & $\begin{array}{l}\text { Zwolnienie z obowiązku } \\
\text { stosowania ustawy o } \\
\text { rachunkowości }\end{array}$ & spółdzielnia socjalna & $\begin{array}{l}\text { dotyczy tych spółdzielni, } \\
\text { których przychody netto ze } \\
\text { sprzedaży towarów, produktów } \\
\text { i operacji finansowych za } \\
\text { poprzedni rok obrotowy nie } \\
\text { przekroczyły równowartości } \\
1,2 \text { mln euro }\end{array}$ \\
\hline 6 & $\begin{array}{l}\text { Dotacja z Państwowego Funduszu } \\
\text { Rehabilitacji Osób Niepełnospraw- } \\
\text { nych dla osoby niepełnosprawnej } \\
\text { (zarejestrowanej w powiatowym } \\
\text { urzędzie pracy jako bezrobotna lub } \\
\text { poszukująca pracy) na założenie lub } \\
\text { wniesienie wkładu członkowskiego } \\
\text { do spółdzielni socjalnej }\end{array}$ & $\begin{array}{l}\text { bezrobotna osoba } \\
\text { niepełnosprawna: } \\
\text { członek założyciel oraz } \\
\text { członek spółdzielni }\end{array}$ & $\begin{array}{l}\text { maksymalnie do wysokości } \\
\text { piętnastokrotnego przeciętnego } \\
\text { wynagrodzenia, tj. do kwoty } \\
60825,6 \mathrm{zł}\end{array}$ \\
\hline 7 & $\begin{array}{l}\text { Możliwość korzystania z wpłat } 1 \% \\
\text { podatku od osób fizycznych jako } \\
\text { organizacja pożytku publicznego }\end{array}$ & spółdzielnia socjalna & $\begin{array}{l}1 \% \text { podatku przekazywanego } \\
\text { przez osoby fizyczne }\end{array}$ \\
\hline
\end{tabular}

Źródło: opracowanie własne.

Pozostała pomoc finansowa ze środków publicznych dostępna dla spółdzielni socjalnych ma charakter fakultatywny. Przyznana tym podmiotom gospodarki społecznej preferencja w podatku dochodowym jest niezwykle rzadko stosowana, gdyż jest to trudne z powodów formalnych. Zdecydowanie bardziej popularna i łatwiejsza do uzyskania pomoc finansowa ze środków publicznych trafia do tych podmiotów gospodarki społecznej w postaci dotacji na założenie spółdzielni socjalnej lub na 
przystąpienie do już istniejącej spółdzielni. Warunkiem jest, aby ubiegająca się osoba była zarejestrowana w powiatowym urzędzie pracy (pup) jako bezrobotna lub poszukująca pracy. Osoba niepełnosprawna musi mieć ponadto ważne orzeczenie o stopniu niepełnosprawności. Źródłem tych dotacji są środki Funduszu Pracy, a w przypadku osób niepełnosprawnych - środki Państwowego Funduszu Rehabilitacji Osób Niepełnosprawnych.

\section{Dotacje z Państwowego Funduszu Rehabilitacji Osób Niepelnosprawnych i Funduszu Pracy jako przejaw finansowego wsparcia spółdzielni socjalnych w Polsce}

W Polsce w latach 2010-2015 wciąż obserwowany jest systematyczny wzrost liczby zarejestrowanych spółdzielni socjalnych. W tym okresie liczba spółdzielni socjalnych zarejestrowanych w Krajowym Rejestrze Sądowym (KRS) zwiększyła się prawie czteroipółkrotnie (rys. 1). O ile na koniec 2010 r. w KRS zarejestrowanych było 276 spółdzielni socjalnych, o tyle w końcu 2015 r. w rejestrze figurowało już 1266 takich spółdzielni.

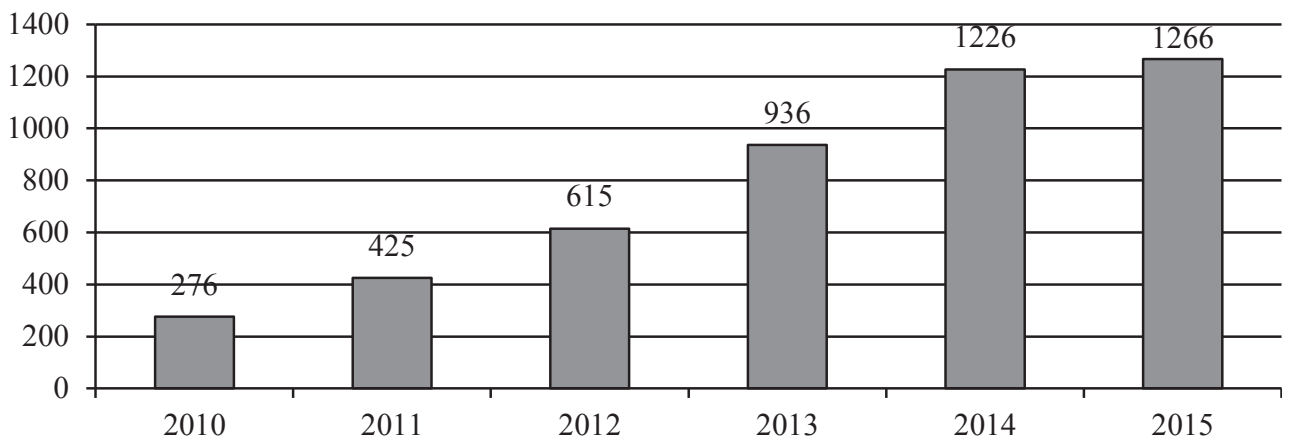

Rys. 1. Liczba spółdzielni socjalnych w Polsce w latach 2010-2015 (stan na koniec roku)

Źródło: opracowanie własne na podstawie danych Departamentu Pożytku Publicznego oraz Ogólnopolskiego Katalogu Spółdzielni Socjalnych, http://www.spoldzielniesocjalne.org.

Gwałtowny przyrost liczby spółdzielni socjalnych nie był bezpośrednio skorelowany ze wzrostem udzielonej pomocy finansowej z państwowych funduszy celowych i wzrostem zatrudnienia osób bezrobotnych (tab. 2).

W latach 2010-2015 przekazano spółdzielniom socjalnym z Funduszu Pracy i PFRON łącznie ponad $14,4 \mathrm{mln}$ zł. Z tej pomocy skorzystało łącznie 984 osób bezrobotnych, zarejestrowanych w urzędach pracy jako bezrobotne lub poszukujące pracy. 130 osób z tego grona stanowiły osoby legitymujące się orzeczoną niepełnosprawnością. Na ich przystąpienie do spółdzielni socjalnej PFRON przekazał ponad 
Tabela 2. Dofinansowanie zatrudnienia w spółdzielniach socjalnych z Funduszu Pracy i PFRON w latach 2010-2015

\begin{tabular}{|l|c|c|c|c|}
\hline \multirow{2}{*}{ Lata } & \multicolumn{2}{|c|}{ Fundusz Pracy } & \multicolumn{2}{c|}{$\begin{array}{c}\text { Państwowy Fundusz Rehabilitacji } \\
\text { Osób Niepełnosprawnych }\end{array}$} \\
\cline { 2 - 5 } & $\begin{array}{c}\text { kwota } \\
\text { dofinansowania }\end{array}$ & $\begin{array}{c}\text { liczba } \\
\text { dotacji }\end{array}$ & $\begin{array}{c}\text { kwota } \\
\text { dofinansowania }\end{array}$ & $\begin{array}{c}\text { liczba } \\
\text { dotacji }\end{array}$ \\
\hline 2010 & 2135900 & 189 & 465905 & 16 \\
\hline 2011 & 819600 & 75 & 435704 & 17 \\
\hline 2012 & 1759300 & 140 & 1077130 & 44 \\
\hline 2013 & 1423100 & 105 & 548644 & 20 \\
\hline 2014 & 2717900 & 189 & 430010 & 19 \\
\hline 2015 & 2133100 & 156 & 479680 & 14 \\
\hline Razem 2010-2015 & 10988900 & 854 & 3437073 & 130 \\
\hline
\end{tabular}

Źródło: opracowanie własne na podstawie danych: Państwowego Funduszu Rehabilitacji Osób Niepełnosprawnych, http://www.pfron.org.pl/bip/budzet-funduszu/1076,Sprawozdania-z-realizacjiplanu-rzeczowo-finansowego-z-dzialalnosci-PFRON-w-lata.html oraz Informacji o funkcjonowaniu spółdzielni socjalnych działających na podstawie ustawy z dnia 27 kwietnia $2006 \mathrm{r}$. o spółdzielniach socjalnych za okres 2010-2015, Departamentu Pożytku Publicznego Ministerstwa Rodziny, Pracy i Polityki Społecznej, http://www.pozytek.gov.pl/files/EKONOMIA\%20 SPOLECZNA/Informacja....\%20OPUBLIKOWANA\%20DPP\%2012.2012.pdf.

3,4 mln zł. Z kolei środki Funduszu Pracy w kwocie prawie 11 mln zł z przeznaczeniem na założenie spółdzielni socjalnej lub wniesienie wkładu do takiej spółdzielni przyznano łącznie 854 osobom bezrobotnym.

W całym okresie widoczne są znaczne wahania kwot i liczby udzielonych dotacji z obu funduszy celowych (rys. 2). Największe wsparcie spółdzielcom socjalnym przyznano w 2014 r. - prawie 3,15 mln zł.

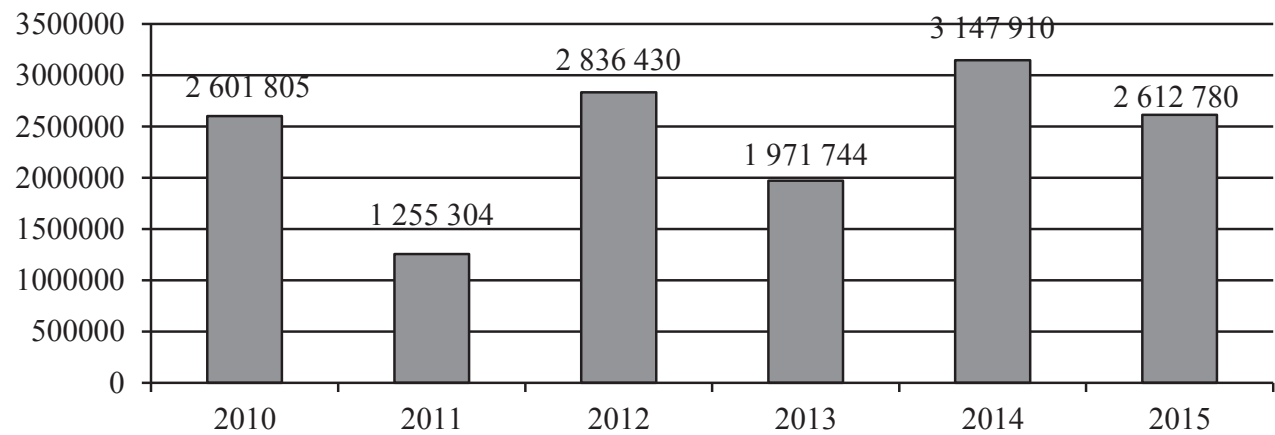

Rys. 2. Łączne kwoty udzielonych dotacji na założenie lub przystąpienie do spółdzielni socjalnych z Funduszu Pracy i PFRON w Polsce w latach 2010-2015

Źródło: opracowanie własne na podstawie danych z tab. 2. 
W 2011 roku Fundusz Pracy i PFRON wyasygnowały na dotacje na założenie lub przystąpienie do spółdzielni socjalnych jedynie niecałe 1,26 mln zł, czyli dwuipółkrotnie mniej niż w najlepszym pod tym względem 2014 roku.

W całym okresie widoczna jest duża zmienność liczby udzielonych dotacji. W 2010 roku z obu funduszy celowych przyznano 205 dotacji. Rok później liczba tych dotacji zmalała przeszło dwukrotnie (rys. 3).

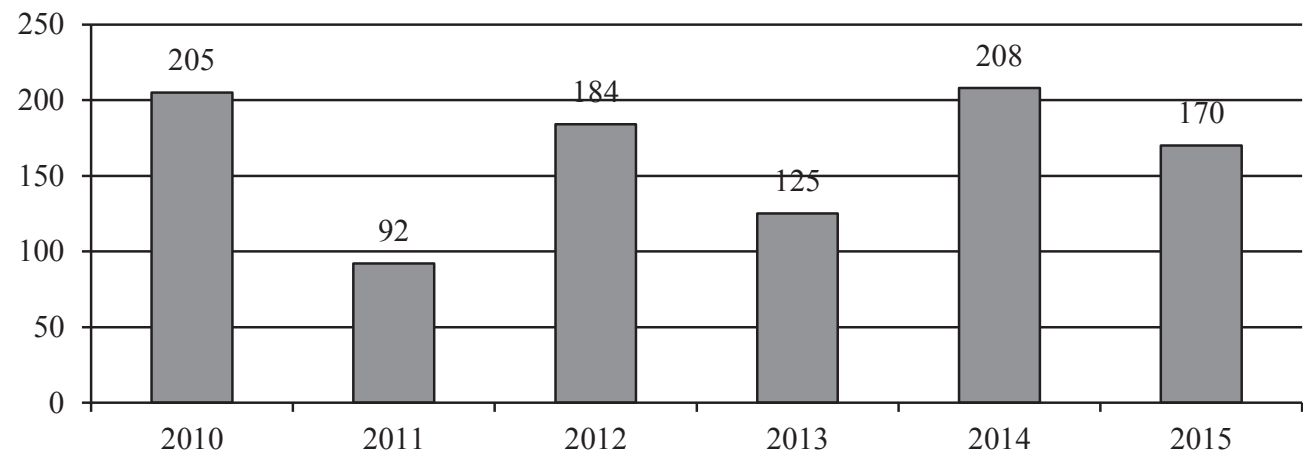

Rys. 3. Liczba udzielonych dotacji z Funduszu Pracy i PFRON na założenie spółdzielni socjalnej lub wniesienie wkładu do spółdzielni socjalnej w Polsce w latach 2010-2015

Źródło: opracowanie własne na podstawie danych z tab. 2.

W kolejnych latach widoczne są również dość znaczne wahania liczby dotacji z jednocześnie zarysowującym się trendem rosnącym.

Przeciętnie znacznie większe kwoty dotacji przekazano z PFRON niż z Funduszu Pracy (rys. 4). Wynikało to przede wszystkim z większych kwot limitów ograni-

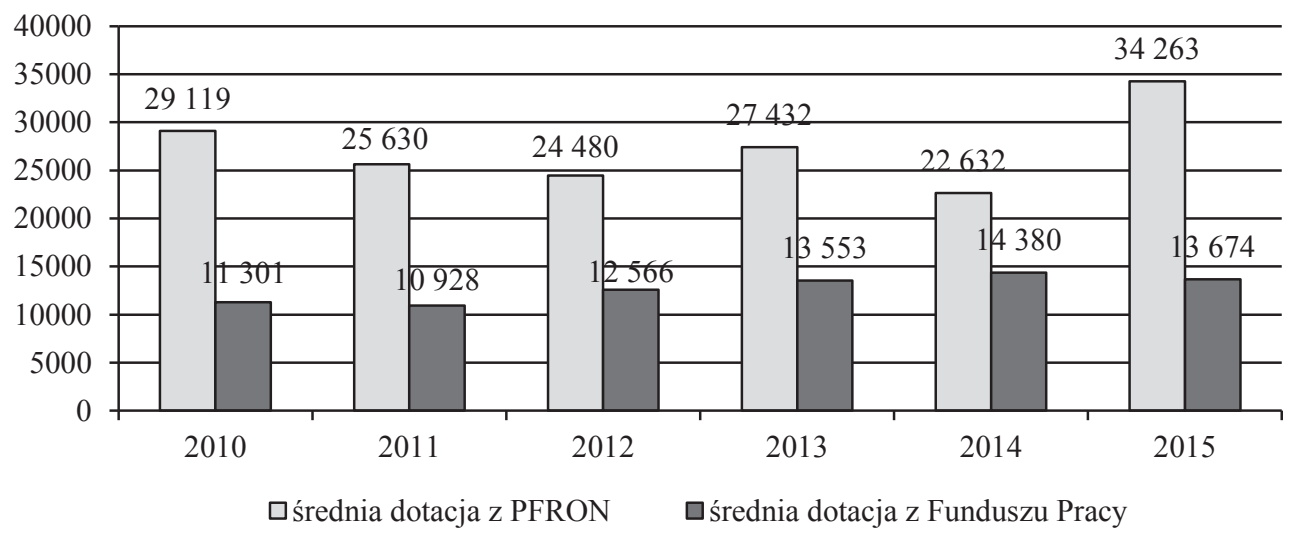

Rys. 4. Średnia kwota dotacji PFRON i z Funduszu Pracy na założenie lub przystąpienie do spółdzielni socjalnej w Polsce w latach 2010-2015

Źródło: opracowanie własne na podstawie danych z tab. 2. 
czających maksymalne pułapy jednorazowego dofinansowania w przypadku osób niepełnosprawnych. Osoba niepełnosprawna mogła otrzymać piętnastokrotność przeciętnego wynagrodzenia, natomiast osoba pełnosprawna - trzy-, czterokrotność przeciętnego wynagrodzenia.

Wsparcie spółdzielni socjalnych w postaci dotacji z Funduszu Pracy w latach 2010-2015 było znacznie większe niż ze środków PFRON (rys. 5).

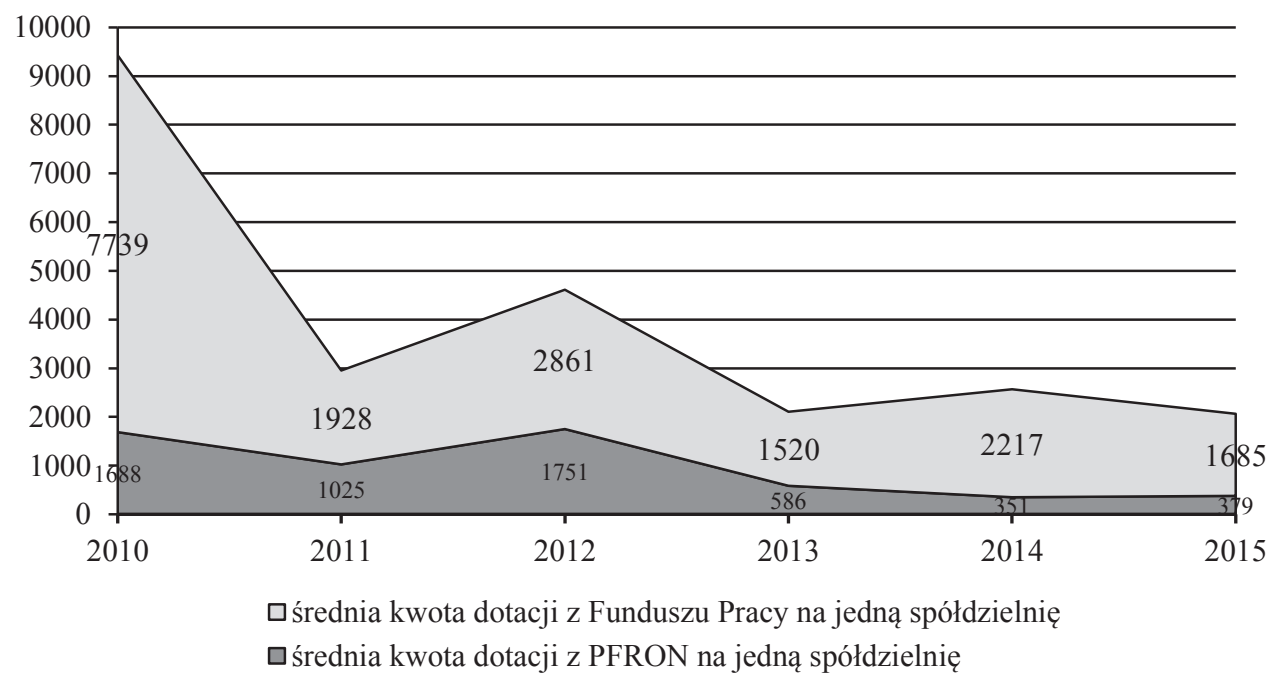

Rys. 5. Średnia kwota dotacji z Funduszu Pracy i PFRON na jedną spółdzielnię w Polsce w latach 2010-2015

Źródło: opracowanie własne na podstawie danych z rys. 1 i tab. 2.

Zauważa się przy tym postępujący spadek pomocy z tych funduszy temu sektorowi przedsiębiorstw społecznych. W 2010 roku przeciętna spółdzielnia socjalna otrzymała łącznie z obu funduszy ponad 9 tys. zł, a w 2015 r. już niewiele ponad 2 tys. zł.

\section{Zakończenie}

Sektor spółdzielni socjalnych w Polsce, podobnie jak w innych krajach, rozwija się bardzo dynamicznie. W Polsce, według stanu na koniec listopada 2016 r., zarejestrowanych było ponad 1300 tego typu przedsiębiorstw gospodarki społecznej, czyli prawie pięciokrotnie więcej niż w 2010 roku. Brakuje szczegółowych i kompletnych badań sytuacji ekonomicznej wszystkich spółdzielni. Natomiast według szacunków w tego typu podmiotach gospodarki społecznej zatrudnienie znajduje w różnych formach i wymiarze czasu od 3 do 5 tys. osób marginalizowanych i zagrożonych wykluczeniem społecznym. Sektor ten odgrywa zatem bardzo ważną rolę w procesie reintegracji osób marginalizowanych z wymienionych przyczyn. 
W teorii przyznanie tym podmiotom pomocy finansowej w postaci zwolnień z niektórych opłat oraz możliwości pozyskania dotacji z Funduszu Pracy i Państwowego Funduszu Rehabilitacji Osób Niepełnosprawnych, a także prawa do wykonywania niektórych usług $\mathrm{w}$ ramach tzw. klauzul społecznych w zamówieniach publicznych wydaje się uzasadnione. Pomoc ta ma stanowić finansową motywację do ich tworzenia i angażowania osób znajdujących się w szczególnie trudnej sytuacji na rynku pracy. W praktyce, mimo znacznych możliwości - według badań autorki niniejszego opracowania ${ }^{2}$ a także w świetle innych badań ${ }^{3}$ - spółdzielnie socjalne borykają się z podstawowymi problemami ekonomicznymi, w tym głównie finansowymi. Znaczna część spośród ankietowanych spółdzielni nie jest w stanie utrzymać się z uzyskiwanych przychodów lub w ogóle nie osiąga takich przychodów. Według szacunków autorki ponad $1 / 3 \mathrm{z}$ widniejących w KRS spółdzielni nie funkcjonuje w praktyce od momentu ich założenia i brak jest woli oraz wiedzy pozwalającej na ich wykreślenie z tego rejestru.

Pomoc finansowa przyznawana spółdzielniom socjalnym pochodzi głównie ze środków publicznych (głównie Funduszu Pracy i PFRON). Głównie są to środki na założenie spółdzielni socjalnych lub przystąpienie do nich. Pomoc ta w ujęciu globalnym generalnie rośnie, lecz cechuje się dużymi wahaniami. Jak podkreślają sami spółdzielcy, udział kwot otrzymanej dotacji w sumie pozyskanych środków (zarówno z tytułu osiąganych przychodów, jak też w postaci innego wsparcia ze strony samorządów) w niektórych przypadkach jest bardzo duży. Część spośród ankietowanych przez autorkę spółdzielców wskazywała, że otrzymanie dotacji na założenie spółdzielni lub na przystąpienie do niej było problematyczne i wymagało przebrnięcia przez skomplikowane procedury. Można też przypuszczać, że istnieje spore grono osób, którym odmówiono wsparcia z Funduszu Pracy lub z PFRON z powodu wyczerpania się środków zaplanowanych w urzędach pracy na ten cel.

Pomoc finansowa udzielona $\mathrm{z}$ obu funduszy w przeliczeniu na jedną spółdzielnię w latach 2010-2015 zmalała czteroipółkrotnie. W ujęciu kwotowym przeciętna kwota dotacji z PFRON była o 10 tys. zł większa niż przyznawana z Funduszu Pracy. Należy jednak pamiętać, że sięgała ona $80-90 \%$ kwot limitów ustawowych, a w przypadku PFRON 30-50\% takich limitów. Ze względu na to, że koszt stworzenia stanowiska i warunków pracy odpowiednich do możliwości osób niepełnosprawnych w wielu wypadkach był znacznie wyższy niż dla osoby pełnosprawnej, można uznać, iż PFRON przyznawał relatywnie mniejszą pomoc niż dysponenci środków Funduszu Pracy.

${ }^{2}$ Autorka niniejszego opracowania przeprowadziła w listopadzie 2016 r. wywiad telefoniczny w 87 spółdzielniach socjalnych, dzięki czemu uzyskała opinię spółdzielców na temat sytuacji ekonomicznej tego sektora przedsiębiorstw.

${ }^{3}$ Między innymi w prezentowanych co dwa lata raportach Ministerstwa Rodziny, Pracy i Polityki Społecznej w postaci: Informacji o funkcjonowaniu spółdzielni socjalnych działających na podstawie ustawy z dnia 27 kwietnia 2006 r. o spółdzielniach socjalnych za okres 2010-2015. 
Biorąc powyższe pod uwagę, trudno jest wskazać, iż dynamiczny rozwój sektora spółdzielni socjalnych w Polsce jest w głównej mierze zależny od kwot przyznawanej pomocy ze środków publicznych (głównie z Funduszu Pracy i PFRON). Bardzo wysokie tempo wzrostu liczby tego typu podmiotów nie wywołuje odpowiedniego tempa wzrostu pomocy przyznawanej ze środków publicznych. Przypuszczalnie również z tego powodu znaczna część spółdzielni nie rozpoczyna faktycznej działalności. Konieczne są zatem zmiany zasad organizowania i finansowania tego typu przedsiębiorstw. Przekazanie samej dotacji nie jest bowiem równoznaczne ze skutecznym wsparciem nowo powstałych dość specyficznych podmiotów gospodarczych. Ustawowe klauzule społeczne w praktyce są rzadko stosowane, a przez część instytucji publicznych wręcz z premedytacją pomijane.

W świetle powyższych badań sformułowana we wstępie hipoteza badawcza została częściowo zweryfikowana pozytywnie.

\section{Literatura}

Bartoli L., Palombo L., 2009, Indexes for the monitoring of social cooperatives' relational behavior, Working Paper, no. 1, "Istituzioni, Metodi Quantitativi e Territorio", Cassino, s. 1-8.

Borzaga C., Santuari A., 2000, Social enterprises in Italy: The experience of social cooperatives, ISSAN Working Paper, no. 15.

Johnson T., Spear R., 2006, Social Enterprise. International Literature Review, GHK.

Legge 8 novembre 1991, nr 381, Disciplina delle cooperative sociali, Pubblicata nella Gazz. Uff. 3 dicembre 1991 (Ustawa z dnia 8 lipca 1991 r. o spółdzielniach socjalnych).

Politaj A., 2010, Spółdzielnie socjalne jako forma aktywizacji zawodowej osób bezrobotnych, Prace Naukowe Uniwersytetu Ekonomicznego we Wrocławiu, nr 113, Ekonomia, Wrocław.

Rusin M., Sobolewska K., Bujko J., 2010, Diagnoza sytuacji osób defaworyzowanych na rynku pracy. Raport podsumowujacy badania realizowane przez Pentor Research International Wrocław dla: Dolnośląskiego Wojewódzkiego Urzędu Pracy w Watbrzychu w ramach projektu pt. „Bariery $i$ szanse wsparcia $i$ obstugi tzw. trudnego klienta instytucji rynku pracy na terenie Dolnego Ślaska", Wałbrzych.

Spear R., 1997, Il vantaggio cooperativo nell'epoca della globalizzazione, Rivista della cooperazione, no. 4.

Thomas A., 2004, The Rise of Social Cooperatives in Italy, International Journal of Voluntary and Nonprofit Organizations, vol. 15, no. 3, September.

Ustawa z dnia 23 kwietnia 1964 r. Kodeks cywilny, DzU 1964, nr 16, poz. 93, z późn. zm.

Ustawa z dnia 16 września 1982 r. Prawo spółdzielcze, DzU 1982, nr 30, poz. 210, tekst jednolity: DzU 1995, nr 54, poz. 288.

Ustawa z dnia 13 czerwca 2003 r. o zatrudnieniu socjalnym, DzU 2003, nr 122, poz. 1143, z późn. zm. Ustawa z dnia 27 kwietnia 2006 o spółdzielniach socjalnych DzU 2006, nr 94, poz. 651.

Ustawa z dnia 14 lipca 2014 r. o działalności pożytku publicznego i o wolontariacie, DzU 2014, poz. 1118 . 